\section{BMJ Paediatrics Open}

\title{
COVID-19-related disruptions to routine vaccination services in India: a survey of paediatric providers
}

Anita Shet (D) , ${ }^{1}$ Baldeep Dhaliwal (D) , ${ }^{1}$ Preetika Banerjee, ${ }^{1}$ Kelly Carr, ${ }^{1}$ Andrea DeLuca, ${ }^{2}$ Carl Britto, ${ }^{3}$ Rajeev Seth, ${ }^{4}$ Bakul Parekh, ${ }^{5}$ Gangasamudra V Basavaraj, ${ }^{5}$ Digant Shastri, ${ }^{5}$ Piyush Gupta ${ }^{5}$

To cite: Shet A, Dhaliwal B, Banerjee $\mathrm{P}$, et al. COVID-19related disruptions to routine vaccination services in India: a survey of paediatric providers. BMJ Paediatrics Open 2021;5:e001060. doi:10.1136/ bmjpo-2021-001060

- Additional supplemental material is published online only. To view, please visit the journal online (http://dx.doi.org/ 10.1136/bmjpo-2021-001060).

Received 10 February 2021 Accepted 30 March 2021

Check for updates

C Author(s) (or their employer(s)) 2021. Re-use permitted under CC BY-NC. No commercial re-use. See rights and permissions. Published by BMJ.

${ }^{1}$ International Health, Johns Hopkins University Bloomberg School of Public Health, Baltimore, Maryland, USA

${ }^{2}$ Amputee Coalition of America, Knoxville, Tennessee, USA ${ }^{3}$ Infectious Disease Resaerch Unit, St John's National Academy of Health Sciences, Bangalore, Karnataka, India ${ }^{4}$ Bal Umang Drishya Sanstha (BUDS), New Delhi, India ${ }^{5}$ Indian Academy of Pediatrics, Navi Mumbai, Maharashtra, India

Correspondence to Dr Anita Shet; ashet1@jhu.edu

\section{ABSTRACT}

The COVID-19 pandemic has led to disruptions in essential health services globally. We surveyed Indian paediatric providers on their perceptions of the impact of the pandemic on routine vaccination. Among 424 (survey 1) and 141 (survey 2) respondents representing 26 of 36 Indian states and union territories, complete suspension of vaccination services was reported by $33.4 \%$ and $7.8 \%$, respectively. In April-June 2020, 83.1\% perceived that vaccination services dropped by half, followed by $32.6 \%$ in September 2020, indicating slow resumption of services. Concerns that vaccine coverage gaps can lead to mortality were expressed by $76.6 \%$. Concerted multipronged efforts are needed to sustain gains in vaccination coverage.

Introduction: Essential health services, including routine childhood immunisations, have been significantly affected by the COVID-19 pandemic. ${ }^{12}$ The nationwide lockdown in India, which was implemented on 24 March 2020, possibly slowed the spread of the SARS-CoV-2 virus and averted deaths due to COVID-19. ${ }^{3}$ However the lockdown also resulted in severe movement restrictions and was associated with disruptions in healthcare service provision and health-seeking activities. ${ }^{4}$ In order to study how COVID-19 control measures may have impacted routine vaccination during this period, we surveyed paediatric healthcare providers in India at two timepoints, during and after the lockdown. The survey assessed the degree of disruption to vaccination services, explored barriers to healthcare provision and identified innovative ways to regain losses in vaccination coverage.

Methods: The surveys were jointly developed by the Johns Hopkins Bloomberg School of Public Health and the Indian Academy of Pediatrics. Survey 1 (April-June 2020) and survey 2 (September 2020) (online supplemental appendix 1) were launched virtually using Qualtrics and distributed to a network of paediatricians and other care providers.
Surveys were anonymous, and distribution took place via email, text messages, telephone, in person and social media platforms such as WhatsApp. Results represented paediatricians' perceptions about vaccination services and were analysed using Stata V.15.1.

Results: Survey 1 and survey 2 recorded 424 and 141 responses, respectively, representing 21 Indian states. Majority of the respondents $(96.0 \%$ and $92.9 \%$, respectively) were paediatricians who worked in predominantly urban and private healthcare centres (table 1). Complete or partial suspension of immunisation services at their respective centres was perceived by $33.4 \%$ (142 of 424) of respondents. In survey 1 (April-June 2020), vaccination services dropped by over half in $83.1 \%$, followed by $32.6 \%$ in survey 2 (September 2020). Interruption of vaccine campaigns for measles, rubella and polio was reported by $37.7 \%$ (160 of 424). Only $38.7 \%$ (164 of 424) of the respondents reported having a plan for catch-up vaccination once these restrictions were eased.

Notable supply-side (healthcare availability) barriers included low availability of healthcare workers, financial constraints and limited supplies such as personal protective equipment (figure 1). Barriers to caregiver vaccine uptake included low awareness of

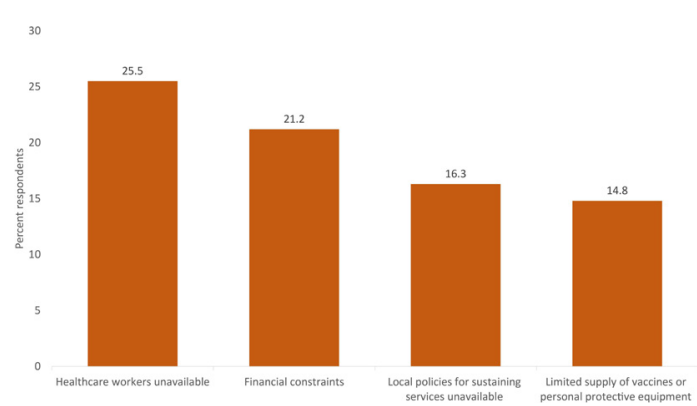

Figure 1 Reported supply-side barriers to routine immunisation services, survey 2 (September 2020). 
Table 1 Survey respondents' characteristics and perceptions around routine vaccination in the context of COVID-19, April-June 2020 (survey 1) and September 2020 (survey 2)

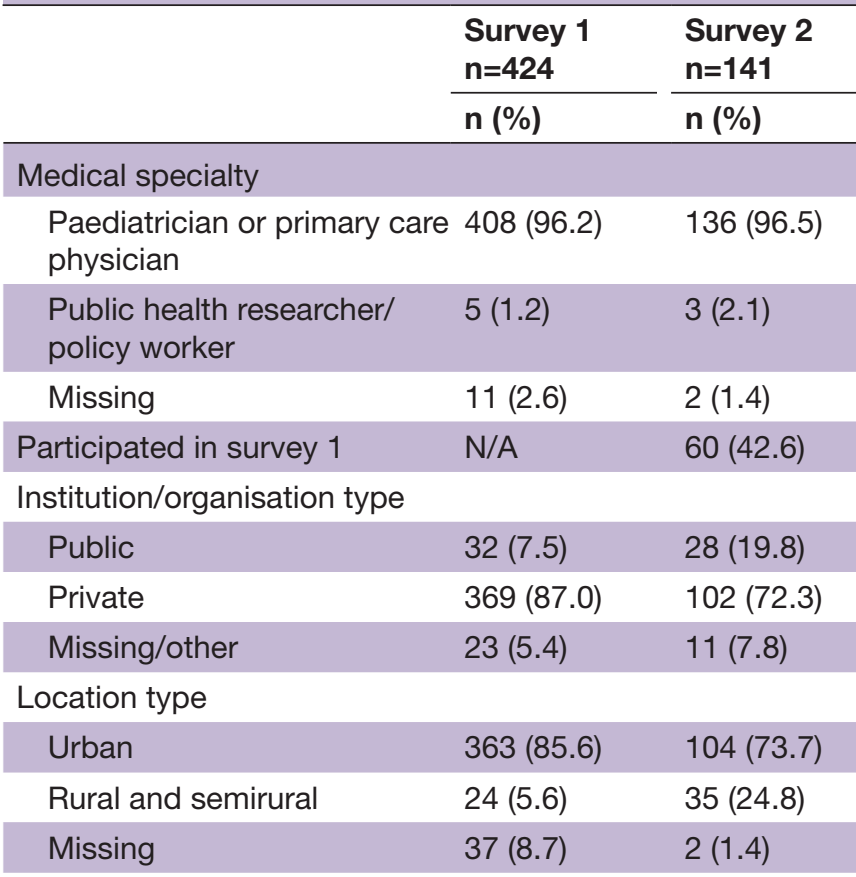

Current volume of those seeking childhood vaccines (as proportion of the prepandemic volume)

\begin{tabular}{|c|c|c|}
\hline $80 \%-100 \%$ & $7(1.8)^{*}$ & $28(19.8)$ \\
\hline $50 \%-79 \%$ & $25(6.3)^{\star}$ & $28(19.8)$ \\
\hline $25 \%-50 \%$ & $168(42.4)^{*}$ & $35(24.8)$ \\
\hline$<25 \%$ & $161(40.7)$ & $11(7.8)$ \\
\hline Missing & $35(8.8)$ & $39(27.7)$ \\
\hline \multicolumn{3}{|c|}{ Reported barriers to caregiver demand } \\
\hline $\begin{array}{l}\text { Unaware services are } \\
\text { available }\end{array}$ & $91(21.4)$ & $33(23.4)$ \\
\hline $\begin{array}{l}\text { Only coming in for } \\
\text { emergencies }\end{array}$ & $73(17.2)$ & N/A $†$ \\
\hline Transportation barriers & $165(38.9)$ & 47 (33.3) \\
\hline $\begin{array}{l}\text { Afraid of contracting } \\
\text { COVID-19 }\end{array}$ & $176(41.5)$ & $91(64.5)$ \\
\hline Financial constraints & $\mathrm{N} / \mathrm{A}$ & $48(34.0)$ \\
\hline \multicolumn{3}{|c|}{ Awareness and availability of a catch-up vaccination plan } \\
\hline Yes & $164(38.7)$ & $39(27.6)$ \\
\hline No & $75(17.6)$ & $30(21.2)$ \\
\hline Don’t know & $108(25.4)$ & $60(42.5)$ \\
\hline Missing & $77(18.1)$ & $12(8.5)$ \\
\hline \multicolumn{3}{|c|}{$\begin{array}{l}\text { What is the long-term impact of pandemic } \\
\text { disruptions? }\end{array}$} \\
\hline No impact & $16(3.7)$ & $4(2.8)$ \\
\hline $\begin{array}{l}\text { Temporary vaccine coverage } \\
\text { gap }\end{array}$ & 203 (47.9) & 108 (76.6) \\
\hline $\begin{array}{l}\text { Vaccine-preventable } \\
\text { outbreaks }\end{array}$ & 137 (32.3) & 35 (24.8) \\
\hline
\end{tabular}

Continued
Table 1 Continued

\begin{tabular}{llll} 
& $\begin{array}{l}\text { Survey 1 } \\
\mathbf{n = 4 2 4}\end{array}$ & & $\begin{array}{l}\text { Survey 2 } \\
\mathbf{n = 1 4 1}\end{array}$ \\
\cline { 2 - 2 } $\mathbf{n}$ (\%) & & $\mathbf{n}(\%)$ \\
\hline $\begin{array}{l}\text { Reduced health services } \\
\text { leading to non-COVID-19 } \\
\text { illness and death }\end{array}$ & $116(27.3)$ & & $40(28.3)$ \\
\hline
\end{tabular}

*This question was asked to a subset of respondents and hence the denominator was 396.

†Not applicable as the question was not asked.

N/A, not applicable.

service availability, transportation limitations, fear of contracting COVID-19 from clinical settings and financial constraints (table 1). While $61.7 \%$ (87 of 141) of the respondents were aware of guidelines on safe provision of vaccinations during the COVID-19 pandemic, $42.5 \%$ (60 of 141) were unaware of national vaccination catch-up programmes. Perceptions that lockdown consequences would result in a vaccine coverage gap persisted in $76.6 \%$ of the respondents. Reported suggestions for catch-up vaccinations included special campaigns, localised communications, door-to-door outreach campaigns, text messaging of immunisation campaigns, and implementing affordable or free immunisation visits.

Discussion: Paediatricians and primary care providers in India indicated that substantial vaccination service disruptions were ongoing in 2020 and expressed concerns about the long-lasting impact of pandemic-related health access barriers. This study was limited by a small sample size and potential selection bias. The high proportion of private practitioners in the survey is not representative of national immunisation coverage, which is predominantly offered by the public health sector in India. ${ }^{5}$ Nevertheless, a majority of Indian states were represented, and early recovery of disruptions seen in the private sector would be reflected in the public sector as well. Similar reports from global surveys indicated substantial disruptions of vaccination services in many countries. ${ }^{6}$ While India has made tremendous progress in reducing vaccination inequities in recent years, ${ }^{7}$ these gains are now at risk of backsliding as a result of pandemic-related disruptions. The way forward should include an increased focus on catch-up campaigns, strong government engagement, effective surveillance and clear public health messaging, as these are critical to restoring immunisation and essential services for women and children.

Contributors $A S, B D$ and $D S$ conceived the study with contributions from $B P$, GVB and PG. BP, PB and ADL developed the study instruments and planned and conducted the study. $\mathrm{PB}, \mathrm{BD}$ and $\mathrm{KC}$ managed the data and conducted analysis of the data. $\mathrm{CB}$ and RS, along with $\mathrm{DS}, \mathrm{BP}, \mathrm{GVB}$ and $\mathrm{PG}$, provided critical review of the instruments and conducted pilot testing. AS, BD and PB prepared the first draft of the manuscript. All authors reviewed the drafts of this manuscript and approved the final version for submission.

Funding This work was supported by the Johns Hopkins Maternal and Child Health Center, India, and the Indian Academy of Pediatrics.

Competing interests None declared. 
Patient and public involvement statement This was a survey of professionals and no patients were involved.

Patient consent for publication Not required.

Ethics approval This study was approved by the Johns Hopkins Bloomberg School of Public Health Institutional Review Board (IRB) under IRB submission number 12405. The IRB determined that proposed activities were 'key informant research' as opposed to 'human subjects research' and determined that the study did not require IRB oversight.

Provenance and peer review Not commissioned; externally peer reviewed.

Supplemental material This content has been supplied by the author(s). It has not been vetted by BMJ Publishing Group Limited (BMJ) and may not have been peer-reviewed. Any opinions or recommendations discussed are solely those of the author(s) and are not endorsed by BMJ. BMJ disclaims all liability and responsibility arising from any reliance placed on the content. Where the content includes any translated material, BMJ does not warrant the accuracy and reliability of the translations (including but not limited to local regulations, clinical guidelines, terminology, drug names and drug dosages), and is not responsible for any error and/or omissions arising from translation and adaptation or otherwise.

Open access This is an open access article distributed in accordance with the Creative Commons Attribution Non Commercial (CC BY-NC 4.0) license, which permits others to distribute, remix, adapt, build upon this work non-commercially, and license their derivative works on different terms, provided the original work is properly cited, appropriate credit is given, any changes made indicated, and the use is non-commercial. See: http://creativecommons.org/licenses/by-nc/4.0/.
ORCID iDs

Anita Shet http://orcid.org/0000-0002-7204-8164

Baldeep Dhaliwal http://orcid.org/0000-0001-5021-3432

\section{REFERENCES}

1 World Health Organization News Release. Essential health survey results. Available: https://www.who.int/news-room/detail/31-08-2020in-who-global-pulse-survey-90-of-countries-report-disruptions-toessential-health-services-since-covid-19-pandemic [Accessed 31 Aug 2020].

2 Chandir S, Siddiqi DA, Setayesh H, et al. Impact of COVID-19 lockdown on routine immunisation in Karachi, Pakistan. Lancet Glob Health 2020;8:e1118-20.

3 Laxminarayan R, Jameel S, Sarkar S. India's battle against COVID-19: progress and challenges. Am J Trop Med Hyg 2020;103:1343-7.

4 The Lancet. COVID-19 in India: the dangers of false optimism. Lancet 2020;396:867.

5 Chokshi M, Patil B, Khanna R, et al. Health systems in India. J Perinatol 2016;36:S9-12.

6 World Health Organization. Global immunization news (GIN) June 2020. immunization and COVID-19. second pulse Poll to help understand disruptions to vaccination and how to respond. Available: https://www.who.int/immunization/GIN_June_2020.pdf

7 Gurnani V, Haldar P, Aggarwal MK, et al. Improving vaccination coverage in India: lessons from intensified mission Indradhanush, a cross-sectoral systems strengthening strategy. BMJ 2018;363:k4782. 